\title{
Seguimiento de la Ictericia Neonatal en Recién Nacidos de Término y Prematuros Tardíos
}

\author{
FERNANDO PERAZZINI FACCHINI ${ }^{1}$, MARIA APARECIDA MEZZACAPPA², \\ IZILDA RODRIGUES MACHADO ROSA ${ }^{2}$, FRANCISCO MEZZACAPPA FILHO ${ }^{3}$, \\ ABIMAEL ARANHA NETTO ${ }^{4}$, SERGIO TADEU MARTINS MARBA ${ }^{4}$
}

1. Professor colaborador voluntário, Setor de Neonatología, Departamento de Pediatria, Faculdade de Ciências Médicas, Universidade Estadual de Campinas (UNICAMP), Campinas, SP, Brasil.

2. Doutora. Professora assistente, Setor de Neonatología, Departamento de Pediatria, Faculdade de Ciências Médicas, UNICAMP, Campinas, SP, Brasil.

3. Professor assistente, Setor de Neonatología, Departamento de Pediatria, Faculdade de Ciências Médicas, UNICAMP, Campinas, SP, Brasil.

4. Doutor. Professor assistente, Setor de Neonatología, Departamento de Pediatria, Faculdade de Ciências Médicas, UNICAMP, Campinas, SP, Brasil.

\section{ABSTRACT \\ Follow-up of Neonatal Jaundice in Term and Late Premature Newborns}

Objective: To report on the results of a project following term and near term newborn infants who were jaundiced during the neonatal period. Methods: Neonates were referred to the follow-up clinic with weight $>2,000 \mathrm{~g}$ and/or gestational age $>35$ weeks, and jaundice at discharge was initially assessed with an Ingram icterometer or Bilicheck and, if indicated, with a Unistat bilirubinometer (Leica). These newborn infants had bilirubinemia at or above the 40th percentile on the nomogram developed by Bhutani. All infants treated with phototherapy while in hospital were reassessed by laboratory methods 24 hours after withdrawal of treatment. Patients were rehospitalized for intensive phototherapy if their level was greater than or equal to $20 \mathrm{mg} / \mathrm{dL}$. Results: From a total sample of 11,259 neonates, $2,452(21.8 \%)$ were referred to the follow-up clinic, $87.2 \%(2,140)$ of whom did return. Eighty returned neonates were readmitted. Return appointments were set for 2,452 patients, $180(7.3 \%)$ of whom had bilirubinemia $>15 \mathrm{mg} / \mathrm{dL}$ at discharge. Of these 180,151 returned for follow-up. Twenty $(13.2 \%)$ were readmitted for treatment. Of the total number of readmitted patients, two newborn infants had levels $>25 \mathrm{mg} / \mathrm{dL}$ and none $>30 \mathrm{mg} / \mathrm{dL}$. All responded rapidly to intensive phototherapy, and there was no need for exchange transfusions. Conclusions: Our results suggest that the regime adopted is effective for detecting and preventing hyperbilirubinemia at risk of causing bilirubin-induced encephalopathy in term and near term newborn infants.

(Key words: Neonatal hyperbilirubinemia/prevention and control, kernicterus/prevention, phototherapy/ utilization).

J. Pediatr. (Rio J.) vol. 83 no. 4 Porto Alegre July/Aug. 2007

\section{ESTE TRABAJO LO PUEDE ENCONTRAR EN EXTENSO EN WWW.SciELO.CL}

